\title{
Morphological adaptation of a planktonic diatom to growth in Antarctic sea ice
}

\author{
Ryszard Ligowski • Richard W. Jordan • \\ Philipp Assmy
}

Received: 17 October 2011/Accepted: 11 December 2011/Published online: 27 December 2011

(C) The Author(s) 2011. This article is published with open access at Springerlink.com

\begin{abstract}
Chaetoceros dichaeta Ehrenberg is one of the most important planktonic diatom species in the Southern Ocean, making a significant contribution to the total biomass in the region. Our observations on both field and culture material have revealed the existence of a specialized form of $C$. dichaeta adapted to living in sea ice. This sea ice form differs from the planktonic form by the shape and orientation of the setae and the aperture length between sibling cells. Thus, the diameter of the chain is equivalent to the apical axes of the cells and is accompanied by a two order of magnitude decrease in minimal space requirement. Here, we report for the first time on the extraordinary overwintering strategy of a planktonic diatom in sea ice facilitated by its rapid morphological adaptation to changing environmental conditions. This morphological plasticity enables it to thrive in the confined space of the sea ice brine matrix and retain its numerical dominance in recurrent growing seasons and has likely evolved to optimally exploit the dynamic ecosystem of the seasonally ice-covered seas of the Southern Ocean.
\end{abstract}

Communicated by U. Sommer.

R. Ligowski $(\square)$

Department of Polar Biology and Oceanobiology,

University of Lodz, Banacha 12, 90-237 Lodz, Poland

e-mail: ligowski@biol.uni.lodz.pl

\section{R. W. Jordan}

Department of Earth and Environmental Sciences, Faculty

of Science, Yamagata University, Yamagata 990-8560, Japan

P. Assmy

Alfred Wegener Institute for Polar and Marine Research,

Am Handelshafen 12, 27570 Bremerhaven, Germany

P. Assmy

Norwegian Polar Institute, Fram Centre, 9296 Troms $\varnothing$, Norway

\section{Introduction}

The Southern Ocean is currently the largest area in which sea ice is being created, extending 18.2-19.4 million $\mathrm{km}^{2}$ in winter and 2.5-3.8 million $\mathrm{km}^{2}$ in summer around Antarctica (Comiso 2010; NASA Earth Observatory 2011). Consequently, large areas that are ice covered in winter exhibit open water conditions during the summer months. Many microscopic plants and animals have successfully adapted to life within the confined matrix of the concentrated brine channels of the sea ice environment (Thomas and Dieckmann 2002). The majority of the biomass in both pelagic (Tréguer et al. 1995) and sea ice communities consists of diatoms (Garrison et al. 1986, 2005; Lizotte et al. 1998), indicating that they have successfully adapted to this dynamic interface between sea ice and water. In particular, those species that have tightly geared their life cycle to both the pelagic realm and the confines of the sea ice brine system will have a competitive advantage over those species with a less flexible life strategy. After their release from the melting sea ice, these diatoms dominate the spring seeding stock in the water column and initiate ice edge as well as open ocean blooms (Smith and Nelson 1990). Ice algal carbon in drifting pack ice is usually dominated by pennate diatoms apparently because they are better adapted to the "benthic" life style dictated by the sea ice environment. However, significant contributions of centric diatoms to sea ice biomass (Garrison 1991; Meiners et al. 2004, 2011) illustrate that at least some species have adapted to the sea ice environment.

The Southern Ocean centric diatom Chaetoceros dichaeta represents such an adaptation since it is a widespread and dominant species in the phytoplankton (Hart 1934, 1942; Ioriya and Kato 1982; Kang and Fryxell 1993; Spiridonov et al. 1996; Xiuren et al. 1996; Hasle and Syvertsen 1997; Smetacek et al. 2002; Riaux-Gobin et al. 2011), as well as 
being a frequent and common diatom in sea ice assemblages (Van Heurck 1909; Heiden and Kolbe 1928; Bujnitsky et al. 1974; Garrison et al. 1983, 1987, 2005; Clarke et al. 1984; Garrison and Buck 1985; Bartsch 1989; Garrison and Close 1993; Gleitz et al. 1998; Watanabe et al. 1990; Moro et al. 2000; Hegseth and von Quillfeldt 2002-see also reviews in Horner 1985 and Garrison 1991). The long setae (spines) protruding from the four corners of the cell are the hallmark feature of species within the genus Chaetoceros and have been interpreted as an adaptation to a planktonic life style. It is therefore particularly surprising that $C$. dichaeta is able to maintain high standing stocks within sea ice despite its unfavorable morphology with respect to the confined space of the sea ice matrix.

In this study, we demonstrate for the first time the unique morphological adaptation of $C$. dichaeta to the sea ice environment and delineate the different morphological features characteristic for the sea ice form from those described in the original species description (and subsequent emendations) for the planktonic form. In the past, specimens of the sea ice form were found in drifting sea ice and thought to be aberrations, but our observations herein could help to explain this apparent conundrum. In the following, we will also deal with the ecological significance of this morphological plasticity.

\section{Methods}

Field sampling

Sea ice samples used in this study were collected during the 7th and 11th Polish Antarctic Expeditions to King George Island in winter 1983 (8 samples) and summer 1986 (one sample), respectively. Samples were obtained of the interior community in drifting sea ice that had become grounded on the shore of Admiralty Bay, near the Polish Antarctic Station "H. Arctowski" at approximately $62^{\circ} 10^{\prime}$ $\mathrm{S}, 58^{\circ} 28^{\prime} \mathrm{W}$. Two samples were also collected during the BIOMASS III study on board the RV "Profesor Siedlecki" from the northern limit of the sea ice at the Weddell-Scotia Confluence (Grelowski and Wojewódzki 1988) in October 1986. Samples were either collected from small pieces of sea ice, which had settled on the shore of Admiralty Bay or they were taken on board manually from the open sea during BIOMASS III Expedition. Due to wave action, the sea ice pieces were constantly submerged prior to collection and therefore equally discolored by diatoms from all sides. Such pieces of brash ice originated from ice floes that are inhabited by "infiltration brash ice assemblages" with high chlorophyll $a$ content characteristic for ice surface infiltration assemblages and a species composition characteristic for ice interior assemblages (Ligowski 1991).
After collection, the surface of the sea ice was washed in filtered sea water to remove plankton cells.

\section{Sample preparation}

Subsamples of sea ice were taken using a 2.5 -cm-diameter ice auger and fixed in formalin at a final concentration of $2 \%$ either immediately after sampling or after gently melting at $4^{\circ} \mathrm{C}$. Two different methods were applied in order to keep cells and chains of Chaetoceros intact for observations at high microscopic resolution. First, an aliquot of all samples (except sample 277) was filtered through a Synpor membrane filter with a pore diameter of $0.4 \mu \mathrm{m}$ for diatom species identification. The volume of sea ice needed for filtration depended on the degree of discoloration (an approximation of pigment concentration) $-1 \mathrm{ml}$ for visibly brown sea ice, $5 \mathrm{ml}$ for visibly light-yellow sea ice and $20 \mathrm{ml}$ for uncolored sea ice. After washing in distilled water and drying, the filters were made transparent using xylene and embedded in Canada balsam with refractive index $(\mathrm{RI})=1.55$ as permanent mounts (Kozlova 1964). Such slides enabled the use of an oil immersion objective lens for quantitative analysis. In the second method, diatoms from sample 277 were washed in distilled water without acid cleaning and after drying embedded in the artificial resin Naphrax $(\mathrm{RI}=1.74)$ (Northern Biological Supplies LTD).

\section{Sample analyses}

LM photomicrographs were taken using a Nikon digital camera DS-5 M mounted on a Nikon Optiphot microscope equipped with $60 \times(\mathrm{NA}=1.4)$ and $100 \times(\mathrm{NA}=1.4)$ planapochromatic objectives with Nomarski interference contrast, while SEM photomicrographs were taken with a Phillips XL20 SEM. Figure 1b was prepared from five photomicrographs using the ArcSoft Panorama Maker software. Measurements were taken with a LUCIA System for Image Processing and Analysis, using LUCIA 4.50 software. Statistical analysis and graphic data presentation were made with Statistica 6.0 (StatSoft Inc.).

Division rate of diatoms was calculated after Eppley (1977):

$\mu=1 / t \log (2)\left(N / N_{\mathrm{o}}\right)$,

where $\mu$-cell divisions/day, $t$-time, $N$-the cell concentration and $N_{\mathrm{o}}$ - the initial cell concentration.

Calculation of minimal space requirement

The volumes of minimal space requirement (MSR) of planktonic and sea ice forms were calculated for single cells and chains containing 5, 10 and 15 cells. The MSR 


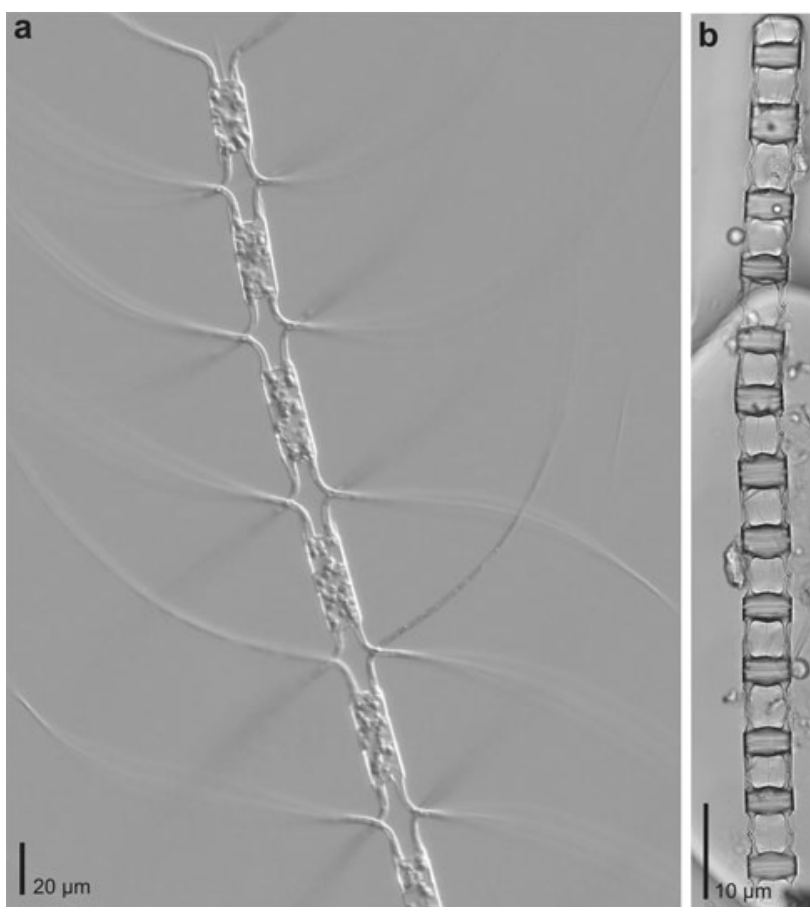

Fig. 1 Light micrographs of $\mathbf{a}$ the planktonic and $\mathbf{b}$ the sea ice form of Chaetoceros dichaeta

volume of the planktonic form of $C$. dichaeta was calculated according to the following geometrical formula: cuboid (Hillebrand et al. 1999; rectangular parallelepiped)

$V=a \times b \times c$

where $V=$ volume, $a=$ width of chain with setae, $b=$ thickness of chain with setae and $c=$ length of chain.

The volume of MSR of the sea ice form of $C$. dichaeta was calculated according to the following geometrical formula (Hillebrand et al. 1999; prism on an elliptic base):

$V=\frac{\pi}{4} \times a \times b \times c$

where $V=$ volume, $a=$ width of cells with setae, $b=$ thickness of cell with setae and $c=$ length of chain. The proportion of cell width to cell thickness was derived from Fig. 2.10.f in Scott and Thomas (2005) for both the planktonic and sea ice forms. A value of $100 \mu \mathrm{m}$ was used for calculating the length of the setae of the planktonic form.

\section{Culture studies}

Clonal cultures of Chaetoceros dichaeta were established by micropipette isolation of single chains during cruise ANT XXI-3 (EIFEX = European Iron Fertilization Experiment) of RV "Polarstern" in the Atlantic Sector of the Southern Ocean $\left(\sim 18^{\circ} \mathrm{E}-02^{\circ} \mathrm{E}, 49^{\circ} \mathrm{S}\right)$ from January 21 to March 25, 2004 (Assmy et al. 2008). Cultures were maintained in $f / 2$ medium enriched with silica (Guillard 1975) at $4-5^{\circ} \mathrm{C}$ with a light: dark cycle of $12: 12 \mathrm{~h}$. Irradiance was adjusted to $20 \mu \mathrm{mol}$ photons $\mathrm{m}^{-2} \mathrm{~s}^{-1}$ and salinity to 34 psu. Sequences of the D1-D3 hypervariable domains of the large subunit (LSU) rDNA were identical for the three different strains used in this study (MM19-C5, MM19-D3 and PA17-D4), indicating that all strains belong to $C$. dichaeta (for further details see Assmy et al. 2008). The sequence of strain MM19-C5 has been deposited in GenBank with accession number EF116486. Light micrographs were taken with a Zeiss AxioCam digital camera. SEM and TEM preparations were made following the methods outlined in Sarno et al. (2005) and observed using a JEOL JSM-6700 SE Filter SEM and a LEO 912AB TEM.

\section{Results}

The planktonic form

Chaetoceros dichaeta Ehrenberg, a species in the subgenus Chaetoceros (ex Phaeoceros), is the type species of the genus (Ehrenberg 1844). Chaetoceros dichaeta normally grows in straight chains or as solitary cells and like other Chaetoceros species, and it has long setae (spines) extending outwards from the four corners of its rectangular cells, differing seta morphology within the chain and characteristic apertures (spacing) between adjoining cells (Rines and Hargraves 1988). In addition, the species has an unusually long, hollow tubular protrusion (rimoportula) extending from the center of each valve face (Assmy et al. 2008).

Field observations of the sea ice form

In samples of pack ice collected close to the South Shetland Islands, we found chains of $C$. dichaeta with a convoluted seta morphology. This sea ice form of $C$. dichaeta differs from the planktonic (Fig. 1a) form by shape, orientation and length of the setae and aperture dimensions (Fig. 1b). In many sea ice samples, the setae of valves within the chain (Fig. 2a, b) and terminal valves (Fig. 2c, d) were parallel to the chain axis, bent inside the aperture between neighboring cells in the former case and within the confines of the valvar margin in the latter case. Thus, the diameter of the whole chain equates to the cell diameter $(17.5 \pm 4.6 \mu \mathrm{m}, n=100)$, whereas the chains of the planktonic form can be several hundred microns wide due to the three-dimensional orientation of the setae. The intercalary seta length of the sea ice form is much shorter than the planktonic form, being $31.1 \pm 8.0 \mu \mathrm{m}$ on average ( $n=100$ ) versus $100-250 \mu \mathrm{m}$ (Assmy et al. 2008, Heiden and Kolbe 1928). The terminal setae of the sea ice form are 

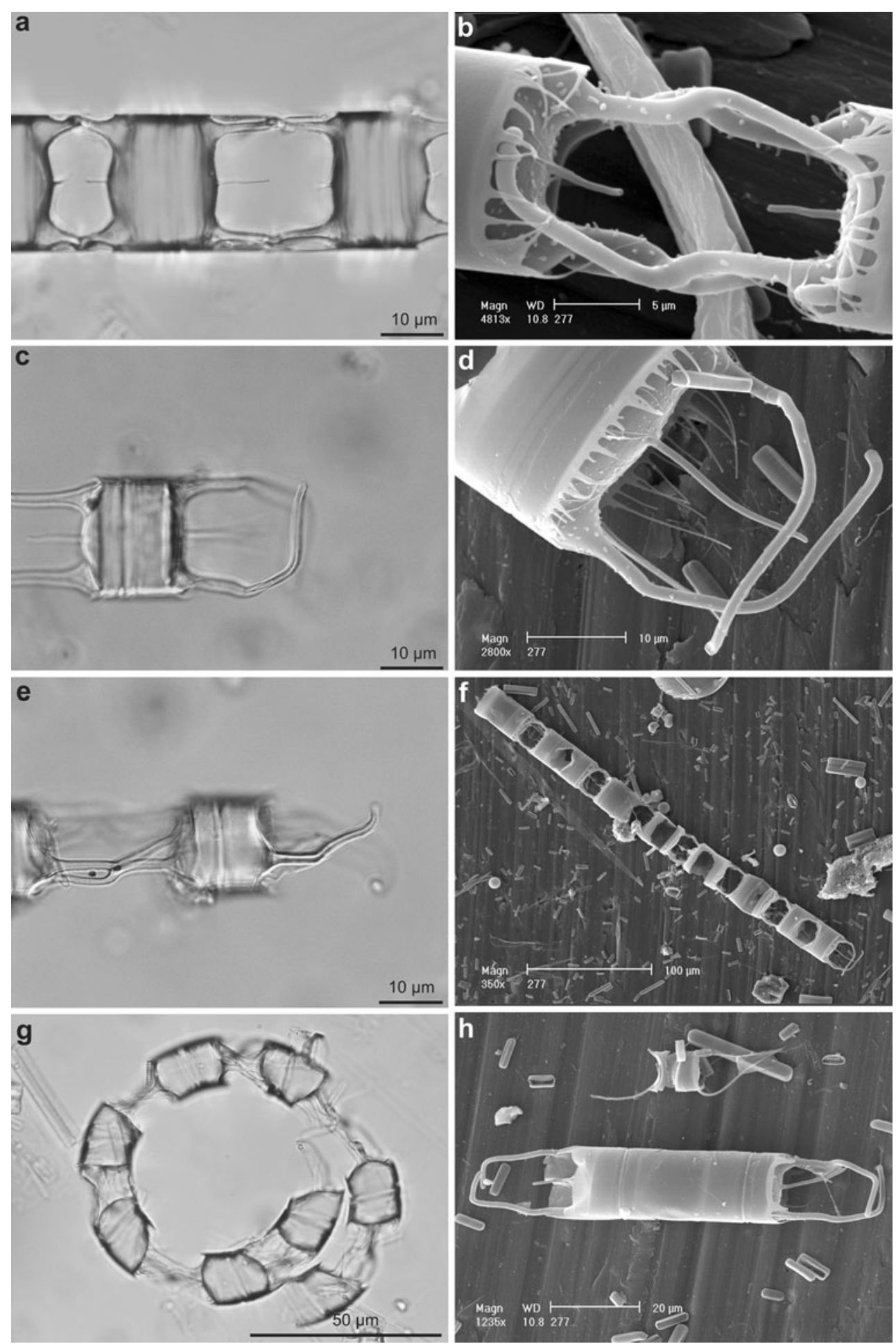

Fig. 2 Detailed light (a, c e, g) and scanning electron (b, d, f, h) micrographs of the sea ice form of $C$. dichaeta. $\mathbf{a}$ and $\mathbf{b}$ apical plane of connection between intercalary cells, $\mathbf{c}$ and $\mathbf{d}$ apical plane of terminal

nearly as short ( $33.1 \pm 4.8 \mu \mathrm{m}, n=50)$ as the intercalary ones. Thus, the intercalary and terminal setae of the sea ice form are 3-8 times shorter than the planktonic form. In lateral view, it is clearly visible that the setae are bent

cell, e transapical plane of connections between intercalary cells and seta of terminal cell, $\mathbf{f}$ straight chain, $\mathbf{g}$ spiraling chain and $\mathbf{h}$ single cell

inside after the point of fusion (Fig. 2e). Subsequent cell divisions inside the sea ice will result in long chains of the sea ice form (Fig. 2f) occasionally in spiraling chains (Fig. $2 \mathrm{~g}$ ) that are unparalleled in the planktonic form. The 

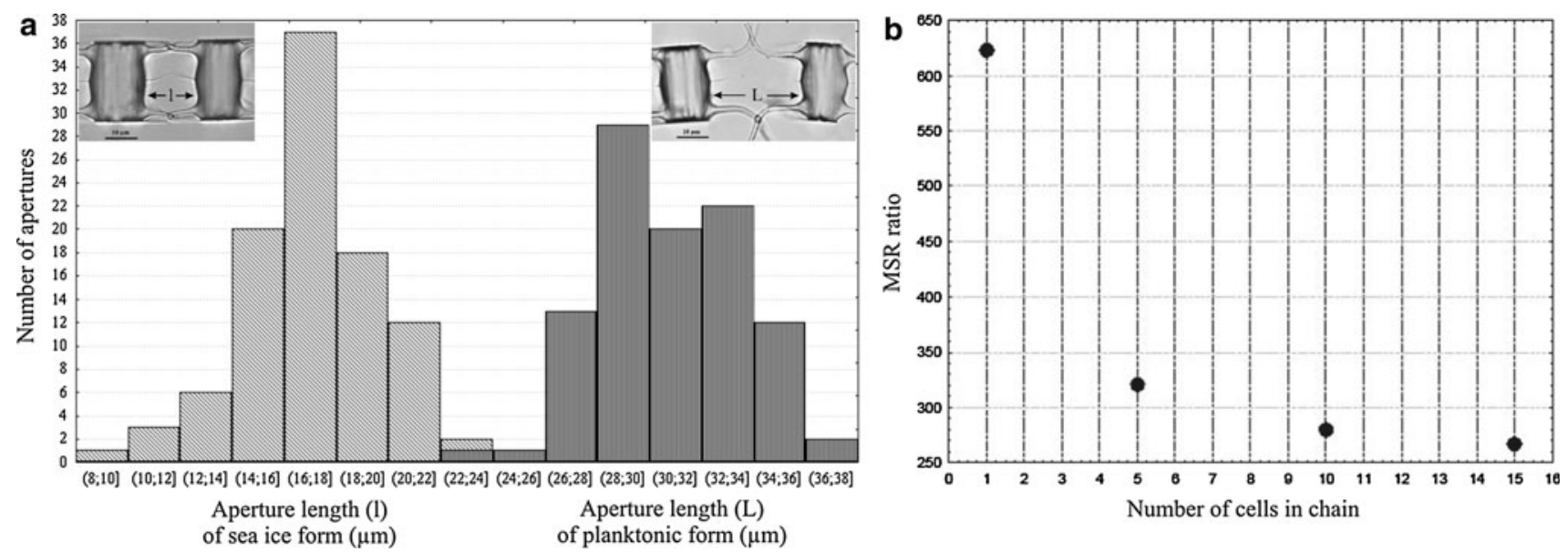

Fig. 3 Morphometric data of sea ice and planktonic forms of $C$. dichaeta. a Length of the aperture between sibling cells within chains of sea ice $(n=100)$ and planktonic $(n=100)$ forms, b the

minimal space requirement (MSR) ratio for the planktonic versus the sea ice form. Note that the ratio declines most rapidly from a solitary cell to a chain of 5 cells and more gradually thereafter

sea ice form was also observed as solitary cells (Fig. $2 \mathrm{~h}$ ). The apertures of the sea ice form are usually much narrower $(17.6 \pm 2.7 \mu \mathrm{m})$ along the pervalvar axis than those of the planktonic form $(31.1 \pm 2.7 \mu \mathrm{m})$ (Fig. 3a), which results in a rather square aperture shape in the former as compared to a rectangular one in the latter. As a result, the chain length of the sea ice form is shorter than in the planktonic one. The combined reduction in seta length and aperture width equates to a more than two orders of magnitude lower MSR of the sea ice form as compared to the planktonic form (Fig. 3b).

\section{Culture observations of the sea ice form}

These field observations are further supported by both LM and EM micrographs from genetically characterized strains of $C$. dichaeta from the Polar Frontal Zone of the Southern Ocean (Fig. 4a-f). The shape and orientation of the setae closely resemble those of the sea ice form. We observed chains with setae bent both inwards and outwards within the same chain (Fig. 4a), as well as specimens in which all the setae in a chain remained trapped within the confines of the valve margin (Fig. 4b).

\section{Intermediate forms}

Thus, we have noticed that the planktonic and sea ice forms are sometimes present in a single population and that both forms can occur even within a single chain. Although a considerable degree of morphological plasticity has been reported for $C$. dichaeta (Assmy et al. 2008), the complete absence or presence of the part of the setae that bends outwards from the cells constitutes a whole new dimension of adaptability, considering that the setae are the hallmark features of the genus Chaetoceros. Below, we outline the possible process whereby one form can transform into the other and discuss the ecological implications of such a phenomenon.

Transition from planktonic to sea ice life style and vice versa

When the planktonic spiny chains of $C$. dichaeta become trapped in sea ice, their somewhat fragile setae are liable to break (Fig. 5a). Subsequent cell divisions within the chain produce the characteristic sea ice form with shortened setae bent inside (Fig. 5a). Terminal valves of the sea ice form with terminal setae bent inside instead of outwards can be created only when chain separation occurs during growth within the sea ice (Fig. 5b) or broken terminal setae (Fig. 5a) of the planktonic form are healed (Fig. 5c). In the sea ice form, the number of cells in a chain can provide information on the number of divisions that have taken place in the sea ice; for example, the chain shown in Fig. $2 \mathrm{f}$ has undergone 5 divisions, while chains having undergone as many as 7 divisions have been observed (Fig. 1b). Once the chain is released from the sea ice, the setae of both the terminal and intercalary (Fig. 5d, e) valves start to grow outwards to take up their normal position and shape. However, this transformation is neither immediate nor synchronous, and so examples of transitional forms can be seen, with chains sporting both sea ice- and planktonic-type cells (Fig. 5f-h).

\section{Discussion}

Morphological adaptation to the sea ice environment

The sea ice form of $C$. dichaeta differs in morphology and dimensions from the original description (Ehrenberg 1844) and subsequent emendations of the planktonic form 

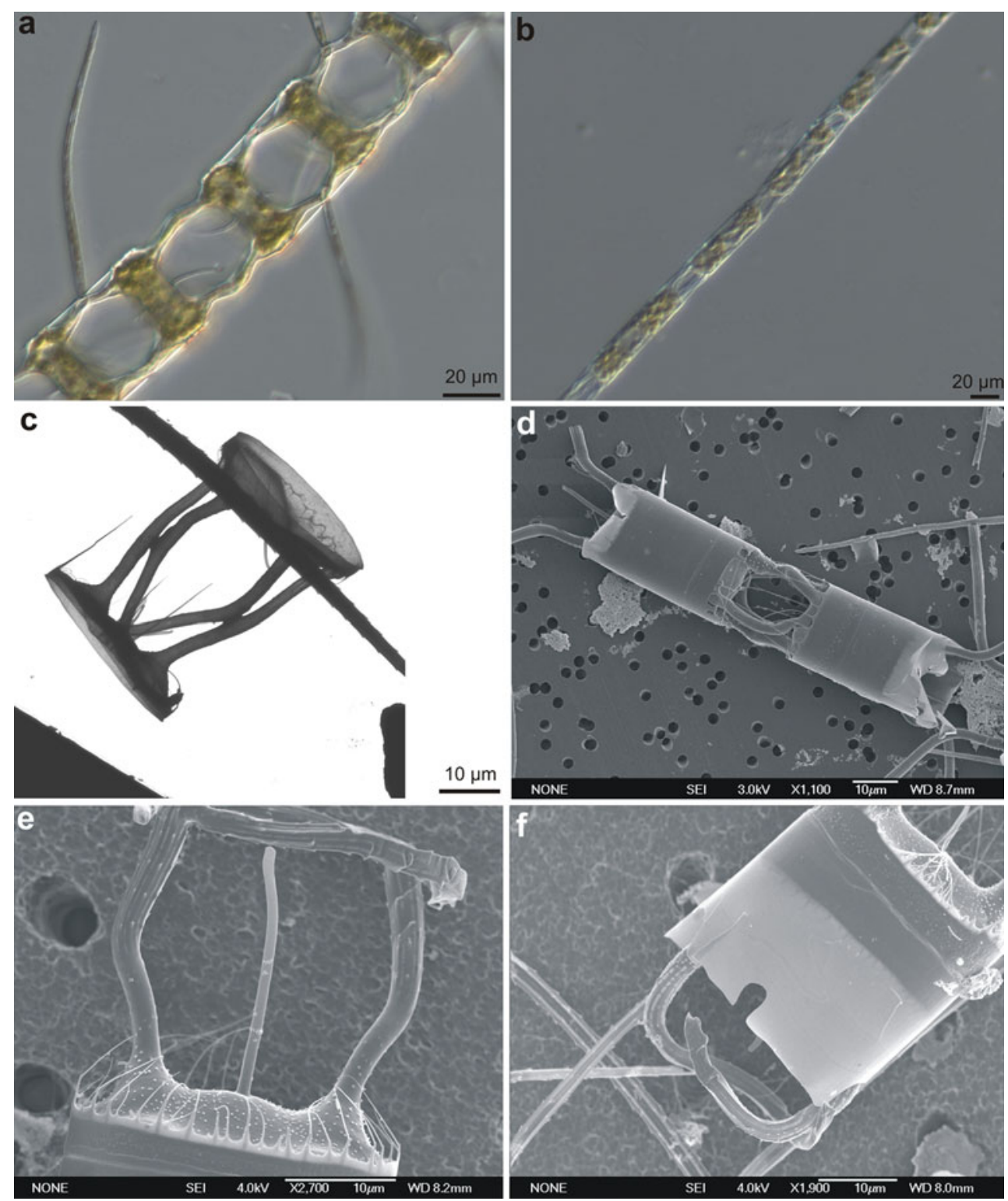

Fig. 4 Light $(\mathbf{a}, \mathbf{b})$ and electron (c -TEM; d, e, f -SEM) micrographs of $C$. dichaeta in culture. a Setae bent both inwards and outwards within the same chain (strain MM19-C5), b chain where all setae remain trapped within the apertures (strain PA17-D4), c two sibling valves interconnected by setae bent inside-note that the upper valve

(Evensen and Hasle 1975, Koch and Rivera 1984, Hernández-Becerril 2002, Assmy et al. 2008). Van Heurck (1909) was the first to show that in sea ice the setae remained trapped inside the aperture between neighboring cells and occasionally the terminal setae were also bent inside the chain axis. Later, similar chains encountered in phytoplankton samples were referred to as anomalies (Mangin 1915). More recently, this convoluted seta morphology within chains of $C$. dichaeta has been reported from Antarctic water (Assmy et al. 2008), sea ice (Bartsch 1989) and sediment (X. Crosta, pers comm.) samples; however, to date, no reasonable explanation has been given is partly covered by the distal portion of a seta of another cell (strain MM19-C5), d intercalary setae trapped within the aperture (MM19D3), e convoluted seta orientation, with the setae bent inwards instead of outwards (MM19-C5), f same as e but maternal girdle bands still cover part of the aperture (MM19-C5)

as to why such chains exist. Differences in the shape and size of the setae and apertures between the planktonic and sea ice forms are the most important morphological features distinguishing the two forms of $C$. dichaeta and result in two orders of magnitude lower MSR in the case of the sea ice form. This morphological plasticity in the vegetative phase of $C$. dichaeta conveys an adaptive advantage in the confined space within sea ice.

Van Heurck (1909) found chains of $C$. dichaeta in sea ice, which differed from those described by Ehrenberg (1844, p. 200). Some of the setae of the sibling cells remained trapped inside the aperture, and the terminal setae 

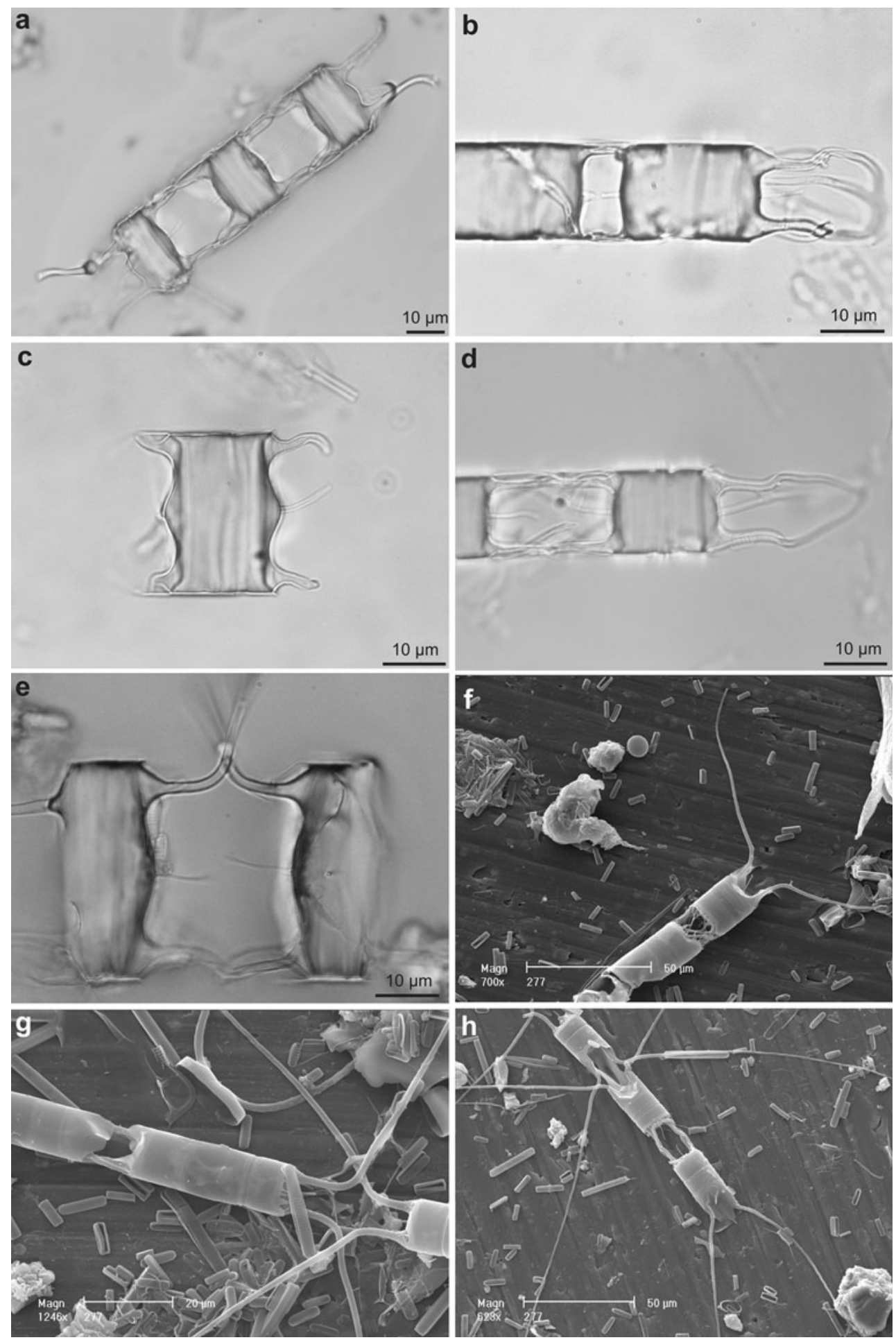

Fig. 5 Light $(\mathbf{a}-\mathbf{e})$ and scanning electron $(\mathbf{f}-\mathbf{h})$ micrographs of C. dichaeta intermediate forms. $\mathbf{a}, \mathbf{b}$ chain with intercalary sea ice form connections and broken planktonic setae in terminal cell $\mathbf{c}$ truncated terminal setae that have apparently healed, d terminal setae of intermediate between sea ice and planktonic form. Note intercalary

were also sometimes bent inside (Van Heurck 1909, Pl.V, Figs 78, 80, 82). Frenguelli (1943) described these setae as broken or worn and both Mangin (1915, Fig. 26 II) and

setae longer than in sea ice form, e one pair of setae bending outwards, f terminal setae of planktonic shape and intercalary setae of sea ice shape, $\mathbf{g}$ sea ice and planktonic intercalary setae within the same chain. Note the smaller aperture in the sea ice as compared to the planktonic form, $\mathbf{h}$ chain with mixed sea ice and planktonic forms

Manguin (1960, Fig. 102) illustrated two adjoined cells of C. dichaeta with terminal setae partly bent inside, which were described as anomalies. However, this convoluted 
seta morphology within chains of $C$. dichaeta has been reported by Jousé (1977, Pl. 68, Fig. 22) and Bartsch (1989, Pl. 1, Fig. E) from Antarctic sea ice samples. These observations of aberrant seta morphology are in accordance with our findings from samples taken from sea ice in Admiralty Bay and the marginal sea ice zone (MIZ) and clonal cultures from the Antarctic Circumpolar Current (ACC). We do not consider these forms of $C$. dichaeta as anomalies, as was earlier assumed (Mangin 1915; Manguin 1960), but as a specialized form occurring in sea ice.

Corethron pennatum is the only diatom species for which movable elements have been observed to date (Thomas and Bonham 1990). During vegetative cell division, the long, barbed spines hinged at the base of the valve are released from the mother cell by an auxiliary ring of short, hooked spines and swivel in their sockets into the desired angle of $45^{\circ}$ with respect to the valve face. In contrast, the orientation of the setae in $C$. dichaeta is not constrained by morphology but by the environmental conditions within the narrow brine channels. Thus, the complex engineering in $C$. pennatum is determined intrinsically, whereas in $C$. dichaeta, the external environmental conditions trigger the changes in seta morphology. Here, for the first time, we can show the rapid morphological adaptation of a diatom species to changing environmental conditions.

\section{Ecological implications}

Many organisms have adapted to living in both sea ice and open water (Smetacek and Nicol 2005), even though the physico-chemical properties inside sea ice are radically different from those in the open ocean (Gleitz and Thomas 1993). The ice edge therefore serves as a distinct boundary for different life cycle stages during the formation and melting of the sea ice (Fryxell 1989), where adaptations are associated with the transition from life in water to sea ice. Planktonic microorganisms are passively incorporated into sea ice during its formation by frazil ice crystals harvesting or scavenging cells and accumulating them at the surface (see Eicken 1992) and/or by wave action on unconsolidated ice (Ackley et al. 1987; Dieckmann et al. 1990; Weissenberger and Grossmann 1998). Microorganisms are trapped within the narrow brine channels of the sea ice, in spaces with a mean diameter of $200 \mu \mathrm{m}$ (Weissenberger et al. 1992), and commonly as narrow as $50 \mu \mathrm{m}$ (Maykut 1985). During ice incorporation, large cells of diatoms can be destroyed and long chains of small cells broken into fragments (Grossmann and Gleitz 1993). It was noted that the space in sea ice restricts colonization by species with long, fragile spines such as Chaetoceros (Bartsch 1989), but during sea ice formation, $C$. dichaeta is one of the diatom species that can be harvested into grease ice
(Tanimura et al. 1990) and is present in newly formed young ice (Garrison et al. 1983; Garrison and Buck 1985; Moro et al. 2000). The change in cell morphology from the planktonic to the sea ice form of $C$. dichaeta reduces the MSR by more than two orders of magnitude and enables C. dichaeta not only to survive, as in the case of Chaetoceros resting spores, but also to grow during the unfavorable conditions in winter sea ice. The sea ice samples used during this study were taken from pack ice discolored by a diatom bloom occurring inside the sea ice. From the time span between sea ice formation (June 15, 1983) and sampling in Admiralty Bay (August 11, 1983), we can speculate on division rates of the sea ice form of $C$. dichaeta during winter. Assuming that the chains in Fig. 1b (13 cells) and Fig. 2f (10 cells) started with one cell when incorporated in sea ice (as evidenced by cells only sporting the sea ice morphology), we can apply Eppley's formula (see Materials and methods) and estimate maximum division rates of the sea ice form we observed ranging between 0.05 and $0.07 \mathrm{~d}^{-1}$. These rates are conservative since we assumed constant growth over the 57-day period. Division rates measured in $C$. dichaeta cultures grown under nutrient and light replete conditions are about an order of magnitude higher (Spies 1987; Hoffmann et al. 2007) than those observed by us in winter. Nevertheless, winter division rates of the sea ice form are considerably higher than microalgal division rates $\left(0.007\right.$ divisions $\left.\mathrm{d}^{-1}\right)$ reported for winter sea ice (Kottmeier and Sullivan 1990). The elevated winter division rates of the $C$. dichaeta sea ice form could be explained by a spell of warmer weather (temperatures slightly above $0^{\circ} \mathrm{C}$ ) between July 26 and August 04, 1983, accompanied by strong winds and wave action (R. Ligowski pers obs), which certainly contributed to changing sea ice conditions. After this weather event, an increase in the abundance of drifting pieces of sea ice, colored brown by diatoms, was observed in coastal waters in different bays (Bujnitsky 1968; Ligowski 1987).

It is safe to assume that the average width in brine channels, cavities and cracks in the sea ice is so narrow that C. dichaeta can only grow there in the sea ice form in order to avoid unnecessary mechanical damage to the delicate setae. Indeed, it has been shown that even small disturbances will immediately stop seta growth (Pickett-Heaps 1998). Mechanical disturbances during seta growth are much more likely encountered within the confined brine channels as compared to the open water column and thus explain the predominance of the sea ice form in the sea ice environment. Intermediate forms as depicted in this study and illustrated in a scanning electron micrograph of C. dichaeta from the Southern Ocean Iron Experiment ( $\mathrm{SOFeX}$ ) featured on the front cover of volume 304 of the journal 'Science' (image by S.J Tanner and B. Breger 2004) are likely the result of either recent release from 
melting sea ice and/or mechanical disturbances in the water column (e.g., handling by copepods). The presence of convoluted setae in $C$. dichaeta cultures that were maintained at temperatures above the freezing point of sea water was likely due to the settling of chains to the bottom of the culture flasks, which might have hampered the emergence of the setae into three-dimensional space characteristic of the planktonic form. However, we cannot rule out the possibility that the sea ice forms found in culture were artifacts of cultivation since the $C$. dichaeta strains had already been maintained in culture for two years at the time the micrographs were taken.

The high abundance of $C$. dichaeta in sea ice in winter was observed when its abundance in open water was very low (Scharek 1991; Gleitz et al. 1998), although C. dichaeta can occur simultaneously in both plankton and sea ice assemblages in winter (Garrison et al. 1993). This seeding strategy will give them an advantage in early summer during the initiation of phytoplankton growth. Our hypothesis is confirmed by the high cell density of $C$. dichaeta in the MIZ or after ice break-up, when it accounted for a large fraction of the total chlorophyll $a$ (Kang and Fryxell 1993) or total phytoplankton abundance (Froneman et al. 1996; Waters et al. 2000; Pakhomov et al. 2001; Gomi et al. 2007; Olguin and Alder 2011; Riaux-Gobin et al. 2011).

Valves of the sea ice form of $C$. dichaeta have been observed in sediments underlying the Indian Sector of the Southern Ocean (Jousé et al. 1962; X. Crosta, pers comm), suggesting that they could be a potential proxy of past sea ice extent.

In this study, we cannot disentangle the selective pressures that led to the formation of the setae in the genus Chaetoceros, but a comprehensive circumscription of the family Chaetocerotaceae (Kooistra et al. 2010) indicates that the setae were not acquired to accommodate plastids in order to improve $\mathrm{CO}_{2}$ or light capture but were acquired first for other reasons. On the other hand, being trapped in the sea ice solves the buoyancy problem, provides an optimal location for maximizing access to the low surface irradiance levels throughout the winter months and minimizes grazer-induced mortality. In this way, the sea ice form of $C$. dichaeta can enjoy continued growth and accumulate over the winter, although at low division rates. Since the transition from the sea ice to the planktonic form does not involve a cell division step, $C$. dichaeta has a clear advantage over many other sea ice edge diatoms that have not evolved such a seeding strategy. Following the melting of the retreating sea ice edge in spring/early summer, the seeding strategy of $C$. dichaeta will therefore enable it to outnumber many other diatom species and maximize its utilization of the new nutrient supply. This is corroborated by bottle incubation (Timmermans et al. 2001) and in situ iron fertilization experiments (Hoffmann et al. 2007) where
C. dichaeta has been shown to respond rapidly to favorable growth conditions. This species might therefore rapidly colonize the water column under favorable growth conditions during the austral spring. The dominance and ecological significance of $C$. dichaeta in Southern Ocean phytoplankton assemblages can therefore be explained by its extraordinary life cycle adaptation to the dynamic icewater interface of polar oceans.

Acknowledgments The field samples were collected during Antarctic expeditions organized by Polish Academy of Sciences. The authors would like to thank M. Montresor for comments on earlier drafts of this manuscript and for providing some of the pictures, L. Armand for help in obtaining data, and X. Crosta for allowing access to unpublished data. P.A. was supported by the Bremen International Graduate School for Marine Sciences (GLOMAR) that is funded by the German Research Foundation (DFG) within the frame of the Excellence Initiative by the German federal and state governments to promote science and research at German universities. We thank three reviewers for their careful reading of the manuscript and helpful comments.

Open Access This article is distributed under the terms of the Creative Commons Attribution Noncommercial License which permits any noncommercial use, distribution, and reproduction in any medium, provided the original author(s) and source are credited.

\section{References}

Ackley SF, Dieckmann GS, Shen HT (1987) Algal and foram incorporation into new sea ice. EOS Trans Am Geophys Union 68:1736

Assmy P, Hernández-Becerril DU, Montresor M (2008) Morphological variability and life cycle traits of the type species of the diatom genus Chaetoceros, C. dichaeta. J Phycol 44:152-163

Bartsch A (1989) Sea ice algae of the Weddell Sea (Antarctica): species composition, biomass, and ecophysiology of selected species. Ber Polarforsch 63:1-110

Bujnitsky VKh (1968) The influence of microscopic organisms on the structure and strength of the Antarctic sea ice. Okeanologija 8:971-979

Bujnitsky VKh, Kozyrenko TF, Shamont'ev VA (1974) Microscopic algae in the fast ice of the Davis Sea. Problemy Arktiki i Antarktiki 45:100-109

Clarke DB, Ackley SF, Kumai M (1984) Morphology and ecology of diatoms in sea ice from the Weddell Sea. CRREL Rep $84-85: 1-41$

Comiso JC (2010) Variability and trends of the global sea ice cover. In: Thomas DN, Dieckmann GS (eds) Sea ice, 2nd edn. WileyBlackwell, Chichester, pp 205-246

Dieckmann GS, Spindler M, Lange MA, Ackley SF, Eicken H (1990) Sea ice: a habitat for the foraminifer Neogloboquadrina pachyderma? In: Ackley SF, Weeks WF (eds) Sea ice properties and processes, CRREL Monograph 90-1. Hanover, New Hampshire, pp 86-92

Ehrenberg CG (1844) Einige vorläufige Resultate seiner Untersuchungen der ihm von der Südpolreise des Captain Ross, so wie von den Herren Schayer und Darwin zugekommenen Materialien über das Verhalten des kleinsten Lebens in den Ozeanen und den grössten bisher zugänglichen Tiefen des Weltmeers vor. Bericht über die zur Bekanntmachung geeigneten Verhandlungen der 
Königlich- Preussischen Akademie der Wissenschaften zu Berlin:182-207

Eicken H (1992) The role of sea ice in structuring Antarctic ecosystems. Polar Biol 12:3-13

Eppley RW (1977) The growth and culture of diatoms. In: Werner D (ed) The biology of diatoms. Blackwell Scientific Publications, Oxford, pp 24-64

Evensen DL, Hasle GR (1975) The morphology of some Chaetoceros (Bacillariophyceae) species as seen in electron microscopes. Nova Hedwigia Beih 53:153-184

Frenguelli J (1943) XVIII Contribución al conocimiento de las diatomeas argentinas. Diatomeas de las Orcadas del Sur. Rev Mus La Plata 5:221-265

Froneman PW, Perissinotto R, McQuaid CD (1996) Dynamics of microplankton communities at the ice-edge zone of the Lazarev Sea during a summer drogue study. J Plank Res 18:1455-1470

Fryxell GA (1989) Marine phytoplankton at the Weddell Sea ice edge: seasonal changes at the specific level. Polar Biol 10:1-18

Garrison DL (1991) Antarctic sea ice biota. Amer Zool 31:17-33

Garrison DL, Buck KR (1985) Sea-ice algal communities in the Weddell Sea: species composition in ice and plankton assemblages. In: Gray JS, Christiansen ME (eds) Marine biology of polar regions and effects of stress on marine organisms. Wiley, Chichester, pp 103-122

Garrison DL, Close AR (1993) Winter ecology of the sea ice biota in Weddell Sea pack ice. Mar Ecol Prog Ser 96:17-31

Garrison DL, Ackley SF, Buck KR (1983) A physical mechanism for establishing algal populations in frazil ice. Nature 306:363-365

Garrison DL, Sullivan CW, Ackley SF (1986) Sea ice microbial communities in Antarctica. Bioscience 36:243-250

Garrison DL, Buck KR, Fryxell GA (1987) Algal assemblages in Antarctic pack ice and in ice-edge plankton. J Phycol 23:564-572

Garrison DL, Buck KR, Gowing MM (1993) Winter plankton assemblage in the ice edge zone of Weddell Sea and Scotia Seas: compositions, biomass and spatial distribution. Deep-Sea Res I 40:311-338

Garrison DL, Gibson A, Coale SL, Gowing MM, Okolodkov YB, Fritsen CH, Jeffries MO (2005) Sea-ice microbial communities in the Ross Sea: autumn and summer biota. Mar Ecol Prog Ser 300:39-52

Gleitz M, Thomas DN (1993) Variation in phytoplankton standing stock, chemical composition and physiology during sea-ice formation in the southeastern Weddell Sea, Antarctica. J Exp Mar Biol Ecol 173:211-230

Gleitz M, Bartsch A, Dieckmann GS, Eicken H (1998) Composition and succession of sea ice diatom assemblages in the eastern and southern Weddell Sea, Antarctica. In: Lizotte MP, Arrigo KR (eds) Antarctic sea ice: biological processes, interactions, and variability. Antarctic Res Ser 73:107-120

Gomi Y, Taniguchi A, Fukuchi M (2007) Temporal and spatial variation of the phytoplankton assemblage in the eastern Indian sector of the Southern Ocean in summer 2001/2002. Polar Biol 30:817-827

Grelowski A, Wojewódzki T (1988) Hydrography of the region between the King George and Elephant Islands (BIOMASS III, October-November 1986). Pol Polar Res 9:165-180

Grossmann S, Gleitz M (1993) Microbial responses to experimental sea-ice formation: implications for the establishment of Antarctic sea-ice communities. J Exp Mar Biol Ecol 173:273-289

Guillard RRL (1975) Culture of phytoplankton for feeding marine invertebrates. In: Smith WL, Chanley MH (eds) Culture of marine invertebrate animals. Plenum Press, New York, pp 29-60

Hart TJ (1934) On the phytoplankton of the south-west Atlantic and the Bellingshausen Sea, 1929-1931. Discov Rep 8:1-268

Hart TJ (1942) Phytoplankton periodicity in Antarctic surface waters. Discov Rep 21:261-356
Hasle GR, Syvertsen EE (1997) Marine diatoms. In: Tomas CR (ed) Identifying marine phytoplankton. Academic Press, San Diego, pp 5-385

Hegseth EN, von Quillfeldt CH (2002) Low phytoplankton biomass and ice algal blooms in the Weddell Sea during the ice-filled summer of 1997. Antarct Sci 14:231-243

Heiden H, Kolbe RW (1928) Die marinen Diatomeen der deutschen Südpolar-Expedition 1901-1903. Deutsche Südpolar-Expedition Botanik 8:450-715

Hernández-Becerril DU (2002) The type species of the diatom genus Chaetoceros: Chaetoceros dichaeta and a possible cryptic species related. Abstracts 17th International Diatom Symposium, Ottawa, Canada, 25-31 August, 2002, p 54

Hillebrand H, Dürselen CD, Kirschtel DB, Pollingher U, Zohary T (1999) Biovolume calculation for pelagic and benthic microalgae. J Phycol 35:403-424

Hoffmann LJ, Peeken I, Lochte K (2007) Effects of iron on the elemental stoichiometry during EIFEX and in the diatoms Fragilariopsis kerguelenesis and Chaetoceros dichaeta. Biogeosciences 4:569-579

Horner RA (1985) Algal species reported from sea-ice. In: Horner RA (ed) Sea ice biota. CRC Press, Boca Raton, pp 191-203

Ioriya T, Kato M (1982) Phytoplankton collected during the FIBEX Cruise of the Umitaka Maru III, 1980-1981; a preliminary report. Trans Tokyo Univ Fish 5:129-144

Jousé AP (ed) (1977) Atlas of microorganisms in bottom sediments of the oceans. Diatoms and silicoflagellates. Publishing House Nauka, Moscow, pp 1-85 Plates

Jousé AP, Koroleva GS, Nagaeva GA (1962) Diatoms in the surface layer of sediment in the Indian sector of the Antarctic. Trudy Inst Okeanologii AN SSSR 61:19-91

Kang S-H, Fryxell GA (1993) Phytoplankton in the Weddell Sea, Antarctica: composition, abundance and distribution in watercolumn assemblages of the marginal ice-edge zone during austral autumn. Mar Biol 116:335-348

Koch P, Rivera P (1984) Contribution of the diatom flora of Chile. III. The genus Chaetoceros Ehr. (subgenus Phaeoceros Gran). Gayana, Botánica 41:61-84

Kooistra WHCF, Sarno D, Hernández-Becerril DU, Assmy P, Di Prisco C, Montresor M (2010) Comparative molecular and morphological phylogenetic analyses of taxa in Chaetocerotaceae (Bacillariophyta). Phycologia 49:471-500

Kottmeier ST, Sullivan CW (1990) Bacterial biomass and production in pack ice of Antarctic marginal ice edge zones. Deep-Sea Res I 37:1311-1330

Kozlova OG (1964) Diatoms of the Indian and Pacific sectors of the Antarctic. Izd Nauka, Moskva

Ligowski R (1987) Sea ice microalgae community of the floating ice in the Admiralty Bay (South Shetland Islands). Pol Polar Res $8: 367-380$

Ligowski R (1991) Sea ice microalgae at the northern boundary of the pack ice between Elephant Island and South Orkney Islands (December 1988-January 1989). Pol Polar Res 12:547-564

Lizotte MP, Robinson DH, Sullivan CW (1998) Algal pigment signatures in Antarctic sea ice. Antarctic Res Ser 73:93-106

Mangin L (1915) Phytoplancton de l'Antarctique. Deuxiéme Expédition Antarctique Française. Sciences Naturelles. Documents Scientifiques, Botanique, pp 1-95

Manguin É (1960) Les diatomées de la Terre Adélie Campagne du "Commandant Charcot" 1949-1950. In: Emberger L, Heim R (eds) Botanique et biologie vegétale. Annales des Sciences Naturelles, série 12:223-363

Maykut GA (1985) The ice environment. In: Horner RA (ed) Sea ice biota. CRC Press, Boca Raton, pp 21-82

Meiners K, Brinkmeyer R, Granskog MA, Lindfors A (2004) Abundance, size distribution and bacterial colonization of 
exopolymer particles in Antarctic sea ice (Bellingshausen Sea). Aquat Microb Ecol 35:283-296

Meiners KM, Norman L, Granskog MA, Krell A, Heil P, Thomas DN (2011) Physico-ecobiogeochemistry of East Antarctic pack ice during the winter-spring transition. Deep-Sea Res II 58: 1172-1181

Moro I, Paccagnella R, Barbante C, Andreoli C (2000) Microalgal communities of the sea ice, ice covered and ice-free waters of Wood Bay (Ross Sea, Antarctica) during the austral summer 1993-94. Mar Ecol 21:233-245

NASA Earth Observatory (2011) http://earthobservatory.nasa.gov/ Features/WorldOfChange/sea_ice_south.php

Olguin HF, Alder V (2011) Species composition and biogeography of diatoms in antarctic and subantarctic (Argentine shelf) waters (37-76 ${ }^{\circ}$ S). Deep-Sea Res II 58:139-152

Pakhomov EA, Ratkova TN, Froneman PW, Wassmann P (2001) Phytoplankton dynamics at the ice-edge zone of the Lazarev Sea (Southern Ocean) during the austral summer 1994/1995 drogue study. Polar Biol 24:422-431

Pickett-Heaps JD (1998) Cell division and morphogenesis of the centric diatom Chaetoceros decipiens (Bacillariophyceae) II. Electron microscopy and a new paradigm for tip growth. J Phycol 34:995-1004

Riaux-Gobin C, Poulin M, Dieckmann G, Labrune C, Vétion G (2011) Spring phytoplankton onset after break-up and sea-ice signature (Adélie Land, East Antarctica). Polar Res 30:1-11

Rines JEB, Hargraves PA (1988) The Chaetoceros Ehrenberg (Bacillariophyceae) flora of Narragansett Bay, Rhode Island, U.S.A. Bibliotheca Phycologica 79:1-196

Sarno D, Kooistra WHCF, Medlin LK, Percopo I, Zingone A (2005) Diversity in the genus Skeletonema (Bacillariophyceae). II. An assessment of the taxonomy of $S$. costatum-like species, with the description of four new species. J Phycol 41:151-176

Scharek R (1991) Development of phytoplankton during the latewinter/spring transition in the eastern Weddell Sea (Antarctica). Ber Polarforsch 94:1-195

Scott FJ, Thomas DP (2005) Diatoms. In: Scott FJ, Marchant HJ (eds) Antarctic marine protists. Australian Biological Resources Study, Australian Antarctic Division, Canberra and Hobart, pp 13-201

Smetacek V, Nicol S (2005) Polar ocean ecosystems in a changing world. Nature 437:362-368

Smetacek V, Klaas C, Menden-Deuer S, Rynearson TA (2002) Mesoscale distribution of dominant diatom species relative to the hydrographical field along the Antarctic Polar Front. Deep-Sea Res II 49:3835-3848
Smith WO Jr, Nelson DM (1990) Phytoplankton growth and new production in the Weddell Sea marginal ice zone in the austral spring and autumn. Limnol Oceanogr 35:809-821

Spies A (1987) Growth rates of Antarctic marine phytoplankton in the Weddell Sea. Mar Ecol Prog Ser 41:267-274

Spiridonov VA, Nöthig E-M, Schröder M, Wisotzki A (1996) The onset of biological winter in the eastern Weddell Gyre (Antarctica) planktonic community. J Mar Syst 9:211-230

Tanimura Y, Fukuchi M, Watanabe K, Moriwaki K (1990) Diatoms in water column and sea ice in Lützow Bay, Antarctica, and their preservation in the underlying sediments. Bull Natn Sci Mus Tokyo Ser C 18:15-39

Thomas DP, Bonham PI (1990) Family Leptocylindraceae. In: Medlin LK, Priddle J (eds) Polar marine diatoms. British Antarctic Survey, Cambridge, pp 105-107

Thomas DN, Dieckmann GS (2002) Antarctic sea ice-a habitat for extremophiles. Science 295:641-644

Timmermans KR, Gerringa LJA, de Baar HJW, van der Wagt B, Veldhuis MJW, de Jong JTM, Croot PL (2001) Growth rates of large and small Southern Ocean diatoms in relation to availability of iron in natural seawater. Limnol Oceanogr 46:260-266

Tréguer P, Nelson DM, Van Bennekom AJ, DeMaster DJ, Leynaert A, Quéguiner B (1995) The silica balance in the world ocean: a reestimate. Science 268:375-379

Van Heurck H (1909) Diatomées. In: Expédition Antarctique Belge. Résultats du Voyage du S.Y. "Belgica" en 1897-1899. Buschmann. Antwerp, pp 1-126

Watanabe K, Satoh H, Hoshiai T (1990) Seasonal variation in ice algal assemblages in the fast ice near Syowa Station in 1983/84. In: Kerry KR, Hempel G (eds) Antarctic ecosystems. Ecological change and conservation. Springer, Berlin, pp 136-142

Waters RL, van den Enden R, Marchant HJ (2000) Summer microbial ecology off East Antarctica $\left(80-150^{\circ} \mathrm{E}\right)$ : protistan community structure and bacterial abundance. Deep-Sea Res II 47: 2401-2435

Weissenberger J, Grossmann S (1998) Experimental formation of sea ice: importance of water circulation and wave action for incorporation of phytoplankton and bacteria. Polar Biol 20: 178-188

Weissenberger J, Dieckmann G, Gradinger R, Spindler M (1992) Sea ice: A cast technique to examine and analyze brine pockets and channel structure. Limnol Oceanogr 37:179-183

Xiuren N, Zilin L, Genhai Z, Junxian S (1996) Size-fractionated biomass and productivity of phytoplankton and particulate organic carbon in the Southern Ocean. Polar Biol 16:1-11 